\title{
HUBUNGAN KREATIVITAS \\ DENGAN HASIL BELAJAR BAHASA INDONESIA
}

\author{
Olin Nita
}

STKIP Yayasan Abdi Pendidikan

olynyaskucih@gmail.com

Submit, 17-10-2019 Accepted, 25-12-2019 Publish, 25-12-2019

\begin{abstract}
ABSTRAK
Tujuan penelitian ini adalah untuk mendeskripsikan kreativitas dengan hasil belajar bahasa Indonesia siswa kelas X SMAN 4 Payakumbuh. Metode yang digunakan adalah metode korelasi. Cara penarikan sampel dengan menggunakan teknik cluster random sampling yang berjumlah 20 orang. Hasil penelitian menemukan bahwa terdapat hubungan yang signifikan antara kreativitas belajar siswa dengan hasil belajar bahasa Indonesia karena hasil pengujian hipotesis membuktikan bahwa $t_{\text {hitung }}$ lebih besar dari $t_{\text {tabel }}$ yaitu, 4,244>1,734. Simpulan, terdapat hubungan yang signifikan antara kreativitas belajar dengan hasil belajar bahasa Indonesia
\end{abstract}

Kata Kunci:Kreativitas, Hasil Belajar

\section{ABSTRACT}

The purpose of this study was to describe creativity with the learning outcomes of Indonesian students in class X SMAN 4 Payakumbuh. The method used was the correlation method. Determination of the sample is done by cluster random sampling or randomly, then which amaunted to 20 students. The results found that there was a significant relationship between student learning creativity and Indonesian language learning outcomes because the results of hypothesis testing proved that tcount was greater than ttable namely, 4.244> 1.734. Conclusion, there is a significant relationship between learning creativity with Indonesian language learning outcomes

Keywords: Creativity, Learning Outcomes

\section{PENDAHULUAN}

Kreativitas siswa merupakan salah satu faktor yang dapat memberikan sumbangan terhadap keberhasilan belajar siswa karena siswa yang kreatif jarang menghadapi masalah dalam belajar. Siswa-siswa yang kreatif mempunyai kemampuan yang tinggi dalam mengenali masalah yang pada akhirnya mereka mampu mencari sendiri penyelesaian dari permasalahan tersebut. Kreativitas siswa merupakan kemampuan mental dan berbagai jenis keterampilan khas manusia yang dapat 
melahirkan pengungkapan unik, berbeda, orisinil, sama sekali baru, indah, efisien, tepat sasaran dan tepat guna".sejalan dengan pendapat

Beda antara ciri-ciri aptitude dan ciri-ciri non aptitude yang berhubungan dengan kreativitas. Berikut ini diuraikan (1) Ciri-ciri aptitude (berfikir kreatif) dari kreativitas: Kelancaran, Kelenturan (fleksibelitas), Orisianalitas dalam berfikir, Elaborasi, (2) Ciri-ciri non aptitude (efektif) dari kreativitas, Kepercayaan diri, Keuletan, Apresiasi estetik, Kemandirian

Hasil belajar setiap siswa berbeda karena kemampuan yang dimiliki juga berbeda. Hasil belajar yang memuaskan akan menjadi dorongan yang positif bagi siswa sehingga membangkitkan semangat belajar. Tetapi siswa akan berpikir secara kritis, kreatif, mampu memecahkan masalah dalam belajar serta mampu mengenal kesanggupan yang ada pada dirinya sendiri. Sedangkan hasil belajar yang kurang memuaskan akan mengurangi semangat belajar siswa, sehingga sebagian siswa yang seperti ini akan mengabaikan pelajaran dan menghambat perkembangan kreativitasnya.

Berbagai fakta ditemukan di dalam pembelajaran bahasa Indonesia adalah siswa tidak serius dalam mengikuti kegiatan pembelajaran, hal ini terlihat dari banyaknya siswa yang ribut dan mengerjakan tugas yang tidak berkaitan dengan pelajaran Bahasa Indonesia. Interaksi antara guru dengan siswa juga belum dapat dilakukan dengan baik karena banyak dari siswa yang hanya menerima apa saja yang disampaikan oleh guru tanpa mengajukan pertanyaan. Sejalan dengan pendapat di atas Slameto (2010) "tinggi rendahnya hasil belajar seseorang dapat dipengaruhi oleh beberapa faktor, diantaranya adalah kreativitas belajar".

Untuk melihat kreativitas belajar siswa dalam proses pembelajaran dapat ditentukan dengan ciri-ciri yang dikemukakan oleh Sudjana (2010) yaitu:Turut serta melaksanakan tugas belajarnya. Disini siswa mau mencari penyelesaian soal-soal yang diberikan dan bahkan mau untuk mengemukakan pendapatnya dalam menyelesaikan soal-soal tersebut. (1) terlibat dalam pemecahan masalah, dalam proses pembelajaran siswa tidak hanya sekedar duduk saja dalam kelas akan tetapi mau memecahkan soal yang diberikan guru. (2) dalam belajar siswa mau bertanya. Namun, ketika guru memberikan latihan, sebagian dari siswa tidak mampu mengerjakannya dan cenderung mencontek kepada teman yang dianggap pintar. 
Hal tersebut menunjukan bahwa kurangnya kreativitas siswa dalam belajar, sehingga mempengaruhi hasil belajar siswa.Siswa yang memiliki kreativitas tinggi hasil belajarnya terlihat lebih baik dibanding siswa yang kurang memiliki kreativitas dalam belajar. Nilai yang diperolehpun belum maksimal, sedangkan kriteria ketuntasan minimal (KKM) yang ditetapkan yaitu $\leq 75$, tetapi sebagian siswa masih belum mencapai KKM tersebut. Ini merupakan gejala yang perlu adanya pengkajian lebih mendalam.

Hasil belajar merupakan kemampuan-kemampuan yang dimiliki siswa setelah ia menerima pengalaman belajarnya. Sudjana (2010) membagi hasil belajar dalam tiga ranah kawasan, yaitu: (1) Ranah kognitif ranah ini berkenaan dengan hasil belajar intelektual yang terdiri dari enam aspek, yakni pengetahuan atau ingatan, pemahaman, aplikasi analisis, sintesis, dan evaluasi. Kedua aspek pertama disebut kognitif tingkat tinggi, (2) ranah afektif ranah iniberkenaan dengan sikap yang terdiri dari lima aspek, yakni penerimaan, jawaban atau reaksi, penelitian, organisasi, dan internalisasi, (3) ranah psikomotorik ranah iniberkenaan dengan hasil belajar keterampilan dan kemampuan bertindak. Ada enam aspek ranah psikomotoris, yakni (1) gerakan refleks, (2) keterampilan gerakan dasar, (3) kemampuan perseptual, (4) keharmonisan atau ketepatan, (5) gerakan keterampilan kompleks, dan (6) gerakan ekspresif dan interpretatif. Sejalan dengan itu Slameto (2010) mengatakan bahwa hasil belajar sebagai suatu proses untuk memperoleh motivasi dalam pengetahuan, keterampilan, kebiasaan, dan tingkah laku serta penguasaan pengetahuan atau keterampilan yang diperoleh dari suatu pembelajaran, seseorang yang berhasil dalam belajar akan terlihat dalam perubahan tingkah laku.

Hasil penelitian Rahayu (2016) terdapat hubungan lingkungan keluarga terhadap hasil belajar sosiologi. Sahabuddin ( 2015) ada hubungan komunikasi belajar mengajar terhadap hasil belajar peserta didik. Karter ( 2014) ada hubungan komunikasi orang tua dan guru dengan prestasi belajar siswa. Muflichah (2016) terdapat hubungan kemampuan komunikasi interpresional guru dengan prestasi belajar siswa. Namun dalam penelitian ini menekankan pada kreativitas belajar siswa terhadap hasil belajar. Kreativitas siswa merupakan kemampuan mental dan berbagai jenis keterampilan khas manusia yang dapat melahirkan pengungkapan unik, berbeda, orisinil, sama sekali baru, indah, efisien, tepat sasaran dan tepat guna 


\section{METODE PENELITIAN}

Penelitian ini termasuk ke dalam jenis penelitian kuantitatif dengan menggunakan metode korelasi. Populasi dalam penelitian ini siswa kelas X SMAN 4 Payakumbuh yang berjumlah 101 orang. Cara penariakn sampael dengan menggunakan teknik cluster random samplingyang berjumlah 20 orang. Adapun instrument yang digunakan dalam penelitian ini adalah angket yang diedarkan kepada siswa yang menjadi sampel penelitian.Angket ini berisi pertanyaan mengenai kreativitas siswa.Skor yang diberikan disusun berdasarkan penilaian yang diberi rentangan nilai yang rendah sampai yang tinggi dengan menggunakan Skala Likert. Angket yang digunakan berdasarkan Skala Likert yang berisi sejumlah pertanyaan yang menyatakan objek yang hendak diungkap. Penskoran atas angket Skala Likert yang digunakan dalam penelitian ini merujuk pada lima alternatif jawaban yaitu: Selalu (SL), Sering (SR), Kadangkadang (KD), Jarang (JR), Sangat Tidak Pernah (TP). Masing-masing diberi bobot 1 sampai 5 untuk jawaban positif dan 5 sampai dengan 1 untuk jawaban negatif.Instrument dalam penelitian ini sebelum diberikan kepada responden sesungguhnya terlebih dahulu diujicobakan, dengan tujuan untuk memperbaiki dan menyempurnakan angket yang akan digunakan untuk pengambilan data yang sebenarnya.

\section{HASIL PENELITIAN}

Adapun proses penelitian yang dilakukan oleh penelitian melakukan pertemuan terhadap responden, memperkenalkan diri dan tujuan dari penelitian yang dilakukan, memberikan angket kepada masing-masing siswa untuk diisi, menerangkan cara pengisian angket, setelah siswa mengisi angket lalu disuruh siswa membuat nama masing-masing baru setelah itu dikumpulkan. data hasil belajar diperoleh dari nilai ujian semester 1 Bahasa Indonesia. Nilai kreativitas belajar siswa yang akan dibahas ada dua hal, yaitu (1) nilai kreativitas belajar siswa, (2) rata-rata nilai kreativitas belajar siswa.

\section{Nilai Kreativitas Belajar Siswa}

Skor yang akan diubah menjadi nilai adalah skor mentah kreativitas belajar. Adapun nilai masing-masing sampel untuk kreativitas belajar secara umum dapat dilihat pada tabel 1 berikut ini. 
Tabel 1

Nilai Kreativitas Belajar

\begin{tabular}{ccccc}
\hline No & Kode Sampel & Jumlah Skor & Nilai & Kualisifikasi \\
\hline 1 & A & 153 & 77 & Baik \\
\hline 2 & B & 155 & 78 & Baik \\
\hline 3 & C & 152 & 76 & Baik \\
\hline 4 & D & 156 & 78 & Baik \\
\hline 5 & E & 161 & 81 & Baik \\
\hline 6 & F & 157 & 79 & Baik \\
\hline 7 & G & 156 & 78 & Baik \\
\hline 8 & H & 153 & 77 & Baik \\
\hline 9 & I & 154 & 77 & Baik \\
\hline 10 & J & 156 & 78 & Baik \\
\hline 11 & K & 161 & 81 & Baik \\
\hline 12 & L & 161 & 81 & Baik \\
\hline 13 & M & 159 & 80 & Lebih dari cukup \\
\hline 14 & N & 149 & 75 & Bebih dari cukup \\
\hline 15 & O & 150 & 75 & Baik \\
\hline 16 & P & 161 & 76 & Baik \\
\hline 17 & Q & 155 & 78 & Baik \\
\hline 18 & R & 157 & 79 & Lebih dari cukup \\
\hline 19 & S & 153 & 77 & 75 \\
\hline 20 & T & 149 & & \\
\hline & & & & \\
\hline
\end{tabular}

Berdasarkan tabel 1, terlihat bahwa perolehan nilai tertinggi adalah 81 , terendah adalah 75. Secara rinci berikut ini akan diuraikan satu persatu perolehan nilai kreativitas belajar secara umum. Nilai 81 diperoleh sebanyak 3 orang, nilai 80 diperoleh sebanyak 1 orang, nilai 79 diperoleh sebanyak 2 orang, nilai 78 diperoleh sebanyak 5 orang, nilai 77 diperoleh sebanyak 4 orang, nilai 76 diperoleh sebanyak 2 orang, nilai 75 iperoleh sebanyak 3 orang. Untuk lebih jelasnya nilai persentase kreativitas belajar secara umum sebagai berikut.

Tabel 2

Klasifikasi Kreativitas Belajar Secara Umum

\begin{tabular}{ccccc}
\hline No & Tingkat Penguasaan & Kualifikasi & Frekuensi & Persentase \\
\hline 1 & $96-100 \%$ & Sempurna & - & - \\
\hline 2 & $86-95 \%$ & Baik sekali & - & - \\
\hline 3 & $76-85 \%$ & Baik & 17 & $85 \%$ \\
\hline 4 & $66-75 \%$ & Lebih dari cukup & 3 & $15 \%$ \\
\hline 5 & $56-65 \%$ & Cukup & - & - \\
\hline 6 & $46-55 \%$ & Hampir cukup & - & - \\
\hline 7 & $36-45 \%$ & Kurang & - & - \\
\hline 8 & $26-35 \%$ & Kurang sekali & - & - \\
\hline 9 & $16-25 \%$ & Buruk & - & - \\
\hline 10 & $0-15 \%$ & Buruk sekali & - & - \\
\hline
\end{tabular}


Berdasarkan tabel 2, dapat disimpulkan bahwa siswa yang memperoleh kualisifikasi baik dengan persentase $85 \%$ berjumlah 17 orang an siswa yang memperoleh kualisifikasi lebih dari cukup engan persentase $15 \%$ sebanyak3 orang.

\section{Rata-rata Nilai Kreativitas Belajar Siswa}

Setelah didapatkan nilai kreativitas belajar siawa seperti yang tertera di atas, selanjutnya adalah mencari nilai rata-rata engan menggunakan rumus mean. Berikut ini apat dilihat nilai kreativitas belajar secara umum.

Tabel 3

Disrtibusi Nilai Kreativitas Belajar Siswa

\begin{tabular}{ccc}
\hline $\mathbf{X}$ & $\mathbf{F}$ & $\mathbf{F X}$ \\
\hline 81 & 3 & 243 \\
\hline 80 & 1 & 80 \\
\hline 79 & 2 & 158 \\
\hline 78 & 5 & 390 \\
\hline 77 & 4 & 308 \\
\hline 76 & 2 & 152 \\
\hline 75 & 3 & 225 \\
\hline & $\sum \mathbf{N}=\mathbf{2 0}$ & $\sum \mathbf{F X}=\mathbf{1 5 5 6}$ \\
\hline
\end{tabular}

Setelah dimasukan kedalam tabel distribisi, selanjutnya data tersebut di masukan kedalam rumus.

$$
\begin{aligned}
& M=\frac{\sum F X}{N} \\
& =1556 \\
& 20
\end{aligned}
$$

$\mathrm{M}=77,8$ dibulatkan menjadi 78

Berdasarkan hasil rumus di atas, terlihat bahwa nilai rata-rata kreativitas belajar siswa adalah 78 dengan kualifikasi baik. Rata-rata nilai untuk kreativitas belajar turut serta melaksanakan tugas belajar adalah 81 kualifikasi baik. Rata-rata nilai untuk kreativitas belajar terlibat dalam pemecahan masalah adalah 80 kualifikasi baik.Ratarata nilai untuk kreativitas belajar mau bertanya adalah 77 kualifikasi baik.Rata-rata nilai untuk kreativitas belajar berusaha mencari berbagai informasi yang diperlukan dalam belajar adalah 77 kualifikasi baik. Rata-rata untuk kreativitas belajar melaksanakan diskusi kelompok adalah 79 kualifikasi baik. 


\section{Nilai Hasil Belajar Siswa}

Untuk mengubah skor menjadi nilai. Skor yang akan diubah menjadi nilai adalah skor mentah hasil belajar. Adapun nilai masing-masing sampel untuk hasil belajar dapat dilihat pada tabel 4 berikut ini.

Tabel 4

Nilai Hasil Belajar

\begin{tabular}{cccc}
\hline No & Kode Sampel & Nilai & Kualisifikasi \\
\hline 1 & A & 84 & Baik \\
\hline 2 & B & 84 & Baik \\
\hline 3 & C & 79 & Baik \\
\hline 4 & D & 88 & Baik sekali \\
\hline 5 & E & 87 & Lebih dari cukup \\
\hline 6 & F & 72 & Baik \\
\hline 7 & G & 81 & Baik \\
\hline 8 & H & 83 & Baik \\
\hline 9 & I & 83 & Baik \\
\hline 10 & J & 80 & Baik \\
\hline 11 & K & 68 & Baik \\
\hline 12 & L & 79 & Baik \\
\hline 13 & M & 85 & Baik \\
\hline 14 & N & 85 & Baik \\
\hline 15 & O & 78 & Baik sekali \\
\hline 16 & P & 82 & Baik \\
\hline 17 & Q & 89 & Baik \\
\hline 18 & R & 80 & Lebih dari cukup \\
\hline 19 & S & 83 & \\
\hline 20 & T & 75 & \\
\hline
\end{tabular}

Berdasarkan tabel 4, perolehan jumlah nilai ujian semester 1 bahasa indonesia siswa adalah: nilai yang tertinggi adalah 89, sedangkan nilai yang terendah adalah 68 . Secara lengkap perolehan nilai untuk nilai ujian semester 1 bahasa indonesia adalah sebagai berikut ini. nilai 89 diperoleh sebanyak 1 orang, nilai 88 diperoleh sebanyak 1 orang, dan nilai 87 di peroleh sebanyak 1 orang, nilai 85 diperoleh sebanyak 2 orang, nilai 84 diperoleh sebanyak 2 orang, nilai 83 diperoleh sebanyak 3 orang, nilai 82 diperoleh sebanyak 1 orang, nilai 81 diperoleh sebanyak 1 orang, nilai 80 diperoleh sebanyak 2 orang, nilai 79 diperoleh sebanyak 2 orang, nilai 78 diperoleh sebanyak 1 orang, nilai 75 diperoleh sebanyak 1 orang, nilai 72 diperoleh sebanyak 1 orang, nilai 68 dipeoleh sebanyak 1 orang. Untuk lebih jelasnya nilai persentase kreativitas belajar siswa sebagai berikut. 
Tabel 5

Klasifikasi Hasil Belajar

\begin{tabular}{ccccc}
\hline No & Tingkat Penguasaan & Kualisifikasi & Frekuensi & Persentase \\
\hline 1 & $96-100 \%$ & Sempurna & - & - \\
\hline 2 & $86-95 \%$ & Baik sekali & 3 & $15 \%$ \\
\hline 3 & $76-85 \%$ & Baik & 14 & $70 \%$ \\
\hline 4 & $66-75 \%$ & Lebih dari cukup & 3 & $15 \%$ \\
\hline 5 & $56-65 \%$ & Cukup & - & - \\
\hline 6 & $46-55 \%$ & Hampir cukup & - & - \\
\hline 7 & $36-45 \%$ & Kurang & - & - \\
\hline 8 & $26-35 \%$ & Kurang sekali & - & - \\
\hline 9 & $16-25 \%$ & Buruk & - & - \\
\hline 10 & $0-15 \%$ & Buruk sekali & - & \\
\hline
\end{tabular}

Bredasarkan tabel 5, dapat disimpulkan bahwa siswa yang memperoleh kualifikasi baik sekalidengan persentase $15 \%$ berjumlah 3 orang, yang memperolehkualifikasibaik dengan persentase $70 \%$ berjumlah 14 orang dan siswa yang memperoleh kualifikasi lebih dari cukup dengan persentase 15\% berjumlah 3 orang.

\section{Rata-rata Hasil Belajar}

Setelah didapatkan perolehan jumlah nilai ujian semester 1 Bahasa Indonesia siswa. Berikut ini dapat dilihat nilai ujian semester 1 Bahasa Indonesia.

Tabel 6

Distribusi Nilai Ujian Semester 1 Bahasa Indonesia Siswa

\begin{tabular}{ccc}
\hline $\mathbf{X}$ & $\mathbf{F}$ & $\mathbf{F X}$ \\
\hline 89 & 1 & 89 \\
\hline 88 & 1 & 88 \\
\hline 87 & 1 & 87 \\
\hline 85 & 2 & 170 \\
\hline 84 & 2 & 168 \\
\hline 83 & 3 & 249 \\
\hline 82 & 1 & 82 \\
\hline 81 & 1 & 81 \\
\hline 80 & 2 & 160 \\
\hline 79 & 2 & 158 \\
\hline 78 & 1 & 78 \\
\hline 75 & 1 & $\mathbf{7 5}$ \\
\hline 72 & 1 & $\mathbf{7 2}$ \\
\hline 68 & 1 & $\mathbf{6 X}=\mathbf{1 6 2 5}$ \\
\hline & $\sum \mathbf{N}=\mathbf{2 0}$ &
\end{tabular}

Setelah dimasukan kedalam tabel distribusi, selanjutnya data tersebut dimasukan kedalam rumus. 


$$
\begin{aligned}
M & =\frac{\sum f x}{N} \\
& =\frac{1625}{20}
\end{aligned}
$$

$\mathrm{M}=81,25$ dibulatkan menjadi 81

Berdasarkan hasil rumus rata-rata di atas, terlihat bahwa hasil rata-rata nilai ujian semester 1 Bahasa Indonesia adalah 81 dengan kualisifikasi baik.

\section{Hubungan Kreativitas Belajar Dengan Hasil Belajar Siswa}

Untuk mencari tingkat hubungan kreativitas dengan hasil belajar bahasa indonesia siswa digunakan rumus produk moment. Data nilai kreativitas secara umum sebagai variabel $\mathrm{X}$ dan nilai ujian bahasa indonesia sebagai variabel Y. Data masingmasing variabel dapat dilihat tabel berikut ini.

Tabel 7

Korelasi Kreativitas dengan Nilai Hasil Belajar

\begin{tabular}{ccccccc}
\hline No & Kode Sampel & $\mathbf{X}$ & $\mathbf{Y}$ & $\mathbf{X}^{\mathbf{2}}$ & $\mathbf{Y}^{\mathbf{2}}$ & $\mathbf{X Y}$ \\
\hline 1 & $\mathrm{~A}$ & 77 & 84 & 5929 & 7056 & 6468 \\
\hline 2 & $\mathrm{~B}$ & 78 & 84 & 6084 & 7056 & 6552 \\
\hline 3 & $\mathrm{C}$ & 76 & 79 & 5776 & 6241 & 6004 \\
\hline 4 & $\mathrm{D}$ & 78 & 88 & 6084 & 7744 & 6864 \\
\hline 5 & $\mathrm{E}$ & 81 & 87 & 6561 & 7569 & 7047 \\
\hline 6 & $\mathrm{~F}$ & 79 & 72 & 6241 & 5184 & 5688 \\
\hline 7 & $\mathrm{G}$ & 78 & 81 & 6084 & 6561 & 6318 \\
\hline 8 & $\mathrm{H}$ & 77 & 83 & 5929 & 6889 & 6391 \\
\hline 9 & $\mathrm{I}$ & 77 & 83 & 5929 & 6889 & 6391 \\
\hline 10 & $\mathrm{~J}$ & 78 & 80 & 6084 & 6400 & 6240 \\
\hline 11 & $\mathrm{~K}$ & 81 & 68 & 6241 & 4624 & 5508 \\
\hline 12 & $\mathrm{~L}$ & 81 & 79 & 6561 & 6241 & 6399 \\
\hline 13 & $\mathrm{M}$ & 80 & 85 & 6400 & 7225 & 6800 \\
\hline 14 & $\mathrm{~N}$ & 75 & 85 & 5625 & 7225 & 6375 \\
\hline 15 & $\mathrm{O}$ & 75 & 78 & 5625 & 6084 & 5850 \\
\hline 16 & $\mathrm{P}$ & 76 & 82 & 5776 & 6724 & 6232 \\
\hline 17 & $\mathrm{Q}$ & 78 & 89 & 6084 & 7921 & 6942 \\
\hline 18 & $\mathrm{R}$ & 79 & 80 & 6241 & 6400 & 6320 \\
\hline 19 & $\mathrm{~S}$ & 77 & 83 & 5929 & 6889 & 6391 \\
\hline 20 & $\mathrm{~T}$ & 75 & 75 & 5625 & 5625 & 5625 \\
\hline & Jumlah & $\mathbf{1 5 5 6}$ & $\mathbf{1 6 2 5}$ & $\mathbf{1 2 1 0 9 8}$ & $\mathbf{1 3 2 5 4 7}$ & $\mathbf{2 6 4 3 4 4}$ \\
\hline
\end{tabular}

$$
\mathrm{R}_{\mathrm{xy}}=\frac{\mathrm{n} \sum \mathrm{xy}-\left(\sum \mathrm{x}\right)\left(\sum \mathrm{y}\right)}{\sqrt{\left\{\mathrm{n} \sum x^{2}-\left(\sum x\right)^{2}\right\}\left\{n \sum y^{2}-\left(\sum y\right)^{2}\right\}}}
$$




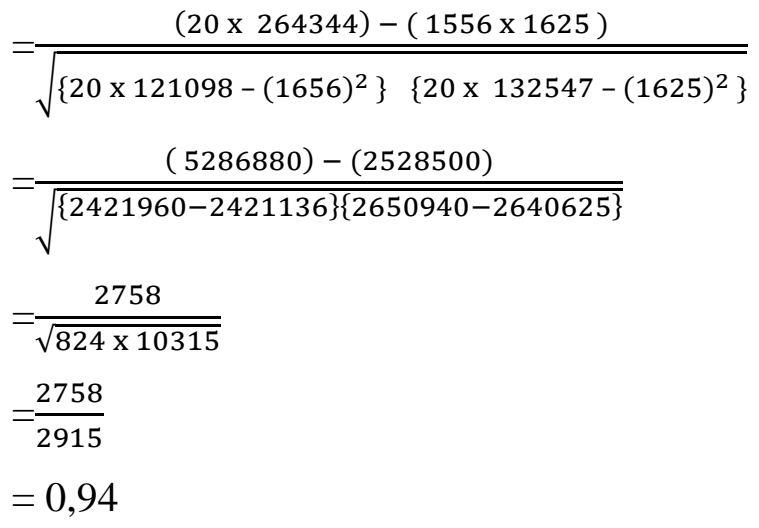

\section{Uji Hipotesis}

$$
\begin{aligned}
\mathrm{t} & =r \frac{\sqrt{\mathrm{n}-2}}{\sqrt{1-r^{2}}} \\
& =0,94 \frac{\sqrt{20-2}}{\sqrt{1-0,94^{2}}} \\
& =\frac{0,94 \sqrt{18}}{\sqrt{1-0,88}} \\
& =\frac{0,94 \times 4,24}{\sqrt{0,88}} \\
& =\frac{3,99}{0,94} \\
\mathrm{t} & =4,244
\end{aligned}
$$

Setelah diperoleh $\mathrm{t}$ dari rumus tersebut, dilanjutkan dengan membandingkan nilai $t_{\text {hitung }}$ dengan $t_{\text {tabel }}$ pada taraf signifikan 0,05 dengan derajat kebebasan $n-2$. Untuk lebih jelasnya dapat dilihat tabel berikut ini.

Tabel 8

Uji Hipotesis Kreativitas Belajar dan Hasil Belajar

\begin{tabular}{cccc}
\hline R & Thitung & n-2 & Ttabel \\
\cline { 3 - 4 } & & & P0,05 \\
\hline 0,94 & 4,244 & 18 & 1,734 \\
\hline
\end{tabular}

Pengujian hipotesis berdasarkan $r_{\text {hitung }}$ 0,94 diperoleh $t_{\text {hitung }}$ 4,244 dengan derajat kebebasan n-2 $(20-2=18)$, dan taraf signifikan 0,05 . Hipotesis diterima jika $t_{\text {hitung }}$ $>t_{\text {tabel }}$. Dengan demikian $\mathrm{H}_{1}$ diterima karena hasil pengujian membuktiakan bahwa $\mathrm{t}_{\text {hitung }}$ lebih besar dari $\mathrm{t}_{\text {tabel }}$ yaitu 4,244 > 1,734. Dapat disimpulkan bahwa terdapat 
hubungan yang signifikan antara kreativitas dengan hasil belajar bahasa indonesia siswa kelas X SMAN 4 Payakumbuh.

\section{PEMBAHASAN}

Kreativitas adalah kemampuan seseorang untuk melahirkan sesuatu yang baru baik berupa gagasan maupun karya nyata yang relatif berbeda dengan apa yang telah ada sebelumnya. Berdasarkan analisis data yang dilakukan dapat diketahui bahwa ratarata nilai kreativitas belajar dan nilai ujian semester 1 bahasa indonesia siswa kelas $\mathrm{X}$ SMAN 4 Payakumbuhadalah 81, yang berada pada kualifikasi baik.

Pada kreativitas belajar, instrumen yang digunakan adalah angket. Angket yang digunakan terdiri dari 6 indikator, yaitu turut serta melaksanakan tugas belajar, terlibat dalam pemecahan masalah, mau bertanya, berusaha mencari berbagai informasi yang diperlukan dalam belajar, melaksanakan diskusi kelompok, memanfaatkan kesempatan yang diberikan guru dalam menyelesaikan soal-soal. Dari pembahasan disimpulkan bahwa hasil penelitian ini sesuai dan saling mendukung dengan kajian teori yang mengatakan bahwa ada hubungan yang positif dan signifikan antara kreativitas dengan hasil belajar. Disampung kreativitas, faktor lingkungan, komunikasi juga mempengaruhi hasil belajar, Hasil penelitian Rahayu (2016) terdapat hubungan lingkungan keluarga terhadap hasil belajar sosiologi. Sahabuddin ( 2015) ada hubungan komunikasi belajar mengajar terhadap hasil belajar peserta didik. Karter ( 2014) ada hubungan komunikasi orang tua dan guru dengan prestasi belajar siswa. Muflichah (2016) terdapat hubungan kemampuan komunikasi interpresional guru dengan prestasi belajar siswa

Artinya semakin baik kreativitas maka hasil belajar siswa juga akan menjadi lebih baik begitu sebaliknya siswa yang memiliki kreativitas yang rendah atau kurang akan memperoleh hasil belajaryang rendah pula. Pada penelitian ini juga diperoleh hasil bahwa kreativitas adalah salah satu faktor yang menentukan hasil belajar. Berdasarkan analisis data pengujian hipotesis yang dilakukan, dengan derajat kebebasan n-2 ( 20$2=18$ ), dan taraf signifikan 0,05 . Hipotesis diterima jika $t_{\text {hitung }}>t_{\text {tabel }}$, maka diperoleh hipotesis diterima yaitu 4,244 > 1, 734. Dapat disimpulkan bahwa terdapat hubungan yang signifikan antara kreativitas belajar dengan hasil belajar bahasa indonesia siswa kelas X SMAN 4 Payakumbuh 


\section{SIMPULAN}

Terdapat hubungan yang signifikan antara kreativitas belajar dengan hasil belajar bahasa Indonesia kelas X SMAN 4 Payakumbuh. Artinya semakin baik kreativitas maka hasil belajar siswa juga akan menjadi lebih baik begitu sebaliknya siswa yang memiliki kreativitas yang rendah atau kurang akan memperoleh hasil belajaryang rendah pula

\section{DAFTAR PUSTAKA}

Karter, J. (2014). Hubungan Komunikasi orang Tua dan guru dengan Prestasi Belajar SIswa SDN Impres 2 Lolo. 1-8

Muflichah, I. (2016). Hubungan Kemampuan Komunikasi Interpresonal Guru dengan Prestasi Belajar Siswa Pada Mata Pelajaran Fikih di Min Kabupaten Sleman. $15-28$.

Rahayu. S. (2016). Hubungan Lingkungan Keluarga terhadap Hasil Belajar Sosiologi di SMA N 16 Padang. 50-59.

Sahabuddin, C. (2015). Hubungan Komunikasi Belajar Mengajar terhadap Hasil Belajar Peserta Didik di SMK N 1 Kabupaten Majeneh. 17-30.

Sudjana, N. (2010). Penilaian Hasil Proses Belajar Mengajar.Bandung : Tarsito.

Slameto. (2010). Belajar dan Faktor yang Mempengaruhinya. Jakarta: Rineka Cipta. 